Wang, CL, Indridasson, T and Saunders MNK (2010) Affective and continuance commitment in public provate partnership. Employee Relations 32.4 396-417

\title{
Affective and Continuance Commitment in Public Private Partnership
}

\begin{abstract}
Purpose: To investigate the effect of the 'transfer' process on relationships between employees' perceived organizational support and affective and continuance commitment within the context of the move to a new employment relationship as part of a Public Private Partnership.
\end{abstract}

Design/methodology/approach: Eight semi-structured interviews informed the design of a questionnaire, which was distributed to facilities management employees of a United Kingdom NHS hospital who had been seconded to a private-sector management company. This resulted in 101 effective responses (33 percent).

Findings: In new forms of employment relationship, employees' perceptions of the 'transfer' process influence significantly their perceptions of the management company and their commitment to it. Positively perceived organizational support from the management company significantly increases affective and continuance commitment to the management company, particularly amongst those who feel positive about the transfer process.

Research limitations: This research focuses upon employee commitment to the management company. Further research is proposed to investigate different foci of commitment as well as the influence of the psychological contract.

Practical implications: The effect of fairness in the 'transfer' process is far reaching, lasting beyond the initial transfer. Both parties should work together to enable a smooth employee 'transfer' process, supervisors particularly having a strong influence on employees' attitudes and behaviour.

Originality/value: There is a lack of research regarding the antecedents and consequences of commitment of employees, who are managed by one but employed by a different organization. This study begins to address this gap.

Keywords: Employee commitment, public private partnership, organizational justice, social exchange theory, perceived organizational support

Paper type: Research paper 


\section{Affective and Continuance Commitment in Public Private Partnership}

\section{Introduction}

Employee commitment continues to be a major focus of inquiry given its predicative power on employee, and organizational, relevant outcomes (Meyer et al., 2002). In a traditional employer-employee relationship, employee perceptions of human resource (HR) practices of their employing organization influence their commitment to the organization (Kinnie, et al., 2005), which, in turn, influences their organizational citizenship behaviour (Van Dyne et al., 1994; Bowen \& Ostroff, 2004). However, recent years have seen the emergence of new forms of employment relationship (CoyleShapiro \& Morrow, 2006; Coyle-Shapiro et al., 2006; Rubery et al., 2002), such as Public Private Partnerships and particularly the Retention of Employment (RoE) Model within the public sector. Within this, whilst staff remain employees of the organization, their management is transferred to a private sector third party who is subsequently also involved in the recruitment and management of other employees for the public sector (nominal) employer. Such employee transfers represent a form of legal secondment to the private sector organization (Prowle, 2006).

Employee commitment in such atypical work arrangements has been subject to relatively limited theoretical and empirical investigation (Gallagher \& McLean Park, 2001; Van Breugel et al., 2005; Walsh \& Deery, 2006). Whilst the transfer of employees' management to a management company inevitably entails change to the employment relationship, the extent to which employees' experiences and perceptions of the transfer influence their commitment to the management company is unclear. In addition, while the employing organization remains the nominal employer, it is the management company that is directly responsible for day-to-day task allocation, 
monitoring, performance evaluation and feedback, and provision of training and support. This suggests that employees' commitment to the management company is also likely to impact upon their job performance.

This study begins to address this research gap by focusing upon two specific research questions, drawing upon data from a United Kingdom (UK) National Health Service (NHS) hospital that as part of a Public Private Partnership had transferred employees' management using the RoE model:

1. To what extent are employees' perceptions of their treatment in the transfer process associated with the perceived organizational support from the management company?

2. To what extent does the impact of the perceived organizational support from the management company on employee commitment vary between employees recruited prior to and post the transfer?

We commence by reviewing research on organizational commitment in the context of new forms of employment relationship from which we derive research hypotheses. The method used to collect data to test these hypotheses is then outlined, and findings, based primarily on regression analyses, presented. Following a discussion of these findings in the context of employee commitment and social exchange theory, we conclude with a consideration of the theoretical and practical implications of this study.

\section{Theoretical Background and Research Hypotheses}

\subsection{New forms of employment relationship}

Within the UK, the public sector has increasingly embraced new forms of employment relationship as a means of improving efficiency and delivering best quality services in 
what is often codified as 'New Public Management'. This paradigm shift was initiated in the late 1970 s and early 1980 s in forms of partnerships and market testing of public services, early initiatives entailing the transfer of the modes of organization and governance by the market principles from the private sector to the public sector (Hood, 1991; Ezzamel \& Willmott, 1993; Clatworthy et al., 2000),

Subsequently in 1992 the UK Government announced the Private Finance Initiative (PFI) with the proclaimed objective of establishing closer, long-term Public Private Partnerships (Allen, 2001). PFI is an outsourcing contractual arrangement where "a consortium of private sector organizations is responsible for designing, building, financing and operating buildings and facilities and associated services that are then used by a public sector organization for the period of the contract, normally 25 to 30 years" (Ismail \& Pendlebury, 2006, p.381). These long-term partnerships are argued to be characterized by relational transparency, interwoven goals, emphasis on dialogue, joint problem-solving, decision-making and production (or service provision); thereby building of enduring relationships through the integration of the partners' efforts to work towards common goals (Sullivan \& Skelcher, 2002). A specific type of PFI scheme in the NHS hospitals stipulates the adoption of the RoE model under which 'non-core' (portering, catering, domestics, laundry and security) staff, whilst remaining NHS employees on full NHS employment terms, are seconded to and, managed by a third party private partner organization (hereafter the management company) (Prowle, 2006). PFI therefore inevitably involves significant change.

Within the literature there is a concern regarding the impact of such initiatives on employee attitudes and behaviour due to the associated atypical employment relationships (Coyle-Shapiro \& Morrow, 2006; Coyle-Shapiro et al., 2006; Rubery et al., 2002; Biggs \& Swailes, 2005). In a study of contract workers in Australian 
manufacturing firms, Benson (1998) warned that previous employee commitment research may have little relevance in the outsourcing context. More specifically, Carrol et al.'s (2005) study of a PFI project revealed that employees, working in such complex organizational contexts, develop commitment and identification beyond organizational boundaries. There is therefore a need to re-examine the antecedents of employee commitment where employees' management is outsourced because,, as Kessler et al. (2004, p.5) concluded, "our knowledge of the impact of outsourcing on employee attitudes and behaviour remains extremely limited".

\subsection{Commitment}

Commitment is defined generally as "the relative strength of an individual's identification with and involvement in a particular organization" (Mowday et al., 1979, p.226). It can be characterized by at least three related dimensions: "a strong belief in and acceptance of the organization's goals and values; a willingness to exert considerable effort on behalf of the organization; and a strong desire to maintain membership in the organization" (Mowday et al., 1979, p.226). Further developing the concept, Meyer and Allen $(1984,1991)$ identified three salient dimensions of employee commitment: affective, continuance and normative. Affective commitment describes an individual's desire to stay with the organization given her/his emotional attachment to, and identification with, the organization (Meyer \& Allen, 1984, 1991). In traditional, ongoing employment relationships, a high level of affective commitment has been found to be related to low employee turnover, low absenteeism and improved job performance (Meyer et al., 2002). Continuance commitment describes an individual's need to remain with the organization resulting from her/his recognition of the costs (tenure, pay, benefits, vesting of pensions and family commitment, etc.) associated with leaving the organization (Meyer \& Allen, 1984, 1991). In contrast, normative commitment reflects an individual's feeling of obligation to maintain organizational 
membership because he/she believes it is morally right to be loyal to, and stay in, the organization.

Although normative commitment is widely recognized as a salient dimension of employee commitment, it has been found to be substantially inter-related with affective commitment (Allen \& Meyer, 1990; Meyer \& Allen, 1997; Morrow, 1993). Specifically, research has found no significant difference between the effects of affective and normative commitment on organizational outcomes (Felfe et al., 2008). Consequently, normative commitment is often excluded from studies; affective and continuance commitment being more commonly used forms (Dunhab et al., 1994; Gautam et al., 2004). In this paper, we follow this tradition of employee commitment research and focus on affective and continuance commitment. In particular, we note that affective commitment of employees has been found to be of paramount importance in the public sector (the context of this study), given that public sector organizations, compared with profit-seeking companies, generally provide less opportunity to reward employees financially (Swailes, 2002). Continuance commitment is also likely to be of importance to this study since the subjects of the study are 'non-core' facilities management staff, who possess a relatively lower level of formal education, are positioned at the bottom of the organizational hierarchy and experience a considerable 'lock-in' effect due to their skills immobility.

\subsection{Social exchange theory and organizational justice}

Employee commitment is underpinned by social exchange theory, which views the employment relationship as a process of resource exchange governed by the norm of reciprocity (Shore \& Wayne, 1993; Coyle-Shapiro et al., 2004), encompassing both ongoing conferment of benefits and continual re-balancing of expectations and obligations (Coyle-Shapiro \& Morrow, 2006). Perceptions of the mutual obligations 
held by the employee and the employer may be the result of formal contracts entailed in an employment relationship or implied by the expectations which two parties hold of each other (Herriot et al., 1997); the latter being captured in the concept of psychological contract (Rousseau, 1990, 2001). Employees reciprocate their employer, based on the extent to which they perceive obligations to them have been fulfilled (Coyle-Shapiro \& Morrow, 2006). The more the employer fulfils obligations and meets expectations, the more employees feel secure and satisfied, and consequently obligated to reciprocate. Conversely, when employees encounter unexpected changes, the perceived reciprocal relationship may be breached. Such changes have become increasingly frequent as organizations respond to competitive pressure, adopting new forms of employment relationship (Kessler et al., 2004). Where these result in a sense of injustice and betrayal (Herriot et al., 1997), this can result in a loss of employee commitment to the organization (Guzzo et al., 1994).

Organizational justice theory highlights that where change occurs, its fairness can be considered in terms of its outcomes, processes and interactions (Colquitt et al., 2006). Perceptions about outcomes of decisions influence the perceptions of distributive justice (Leventhal, 1976). Perceptions about the processes used to arrive at, and to implement, these decisions form the basis of two further dimensions of justice that are sometimes treated as one in the literature: procedural justice and interactional justice (e.g. Cropanzano \& Greenberg, 1997). Procedural justice focuses on employee perceptions of fairness of procedures used to make decisions (Thibaut \& Walker, 1975). This has been distinguished from interactional justice, which focuses on employees' perceptions about fairness of interpersonal treatment received (often from supervisors or direct line managers) during implementation (Bies \& Moag, 1986). However, there has been considerable debate concerning interactional justice. Initially, researchers (e.g. Bies \& Moag, 1986; Greenberg, 1993) suggested that it consisted of two distinct 
types of interpersonal treatment: treatment of people (interpersonal justice) and explanations provided to people (informational justice). Subsequently, it was argued that, as interactional justice produces the same type of perceptual outcomes as procedural justice, it should be considered a facet of procedural justice rather than as a separate dimension (e.g. Cropanzano \& Greenberg, 1997). Nevertheless, more recent research has suggested that procedural and interactional justice, although related, represent distinct constructs (Cohen-Carash \& Spector, 2001) that are uniquely related to worker attitudes and behaviour (Bies, 2006).

In the context of a new form of employment relationship such as the PFI using the RoE model the outcome of employment (e.g. salary, performance evaluation and promotion) by the NHS for many employees remains constant (Prowle, 2006). Therefore, distributive justice is not the focus of this study. Rather, we focus on procedural and interactional justice during the employee transfer process. As indicated by research on change in UK local authorities (Saunders \& Thornhill, 2004; Thornhill \& Saunders, 2003), employees' perceived fairness of the procedures used and the interactions occurring during the process are important predictors of their attitudes. Positive perceptions of procedural and interactional justice imply the organization's respect of employees' rights and help form a positive view regarding perceived organizational support (Loi et al., 2006; Moideenkutty et al., 2001), that is, employees' beliefs concerning the extent to which the organization values their contributions and cares about their well-being (Eisenberger et al., 1986). Consequently higher levels of perceived organizational justice are likely to be associated with a higher level of organizational support, reflecting employees' perceptions on the organization's commitment to the employees (Shore \& Tetrick, 1991; Shore \& Wayne, 1993). 


\subsection{Research hypotheses}

To date research that builds on social exchange theory to explain employee commitment has focused largely on a two-way exchange between the employer and the employee only. However, in the light of the new form of employment relationship, there is a need to explore whether employees' perceptions of procedural and interactional justice originated by one party (the employer) influence their perceptions of, and attitudes towards, another party (the management company). In relation to this, research indicates employees view the employer and the management company as two inter-connected organizations, and the employee transfer process a continuous event rather than isolated episodes. For example, Coyle-Shapiro et al. (2006) caution that employees' perceptions of support from the client company may be influenced by how management in their employing organization communicates information about the recipient client company. This is related to our first research question: "to what extent are employees' perceptions of their treatment in the transfer process associated with perceived organizational support from the management company"; and leads to our first set of hypotheses:

$\mathrm{H}_{1 \mathrm{a}}$ : Perceived procedural justice in the employee transfer process is positively associated with employees' perceived organizational support from the management company.

$\mathrm{H}_{1 \mathrm{~b}}$ : Perceived interactional justice in the employee transfer process is positively associated with employees' perceived organizational support from the management company.

Social exchange theory posits that employees perceive a high level of organizational support as genuine care by an organization (Eisenberger et al., 1986). Under the norm 
of reciprocity, employees feel obliged to respond positively in the form of positive attitudes and behaviour. Effective organizational support also encourages employees to identify with the organization's values, being positively related to organizational commitment (Eisenberger et al., 1986). In particular, research has found that agency and long-term contract employees' perceived organizational support from a client company is related to their affective commitment to that company (Liden et al., 2003; Coyle-Shapiro et al., 2006). Nonetheless, the majority of empirical evidence on organizational support and employee commitment is based on studies of traditional employment relationship. This leads to our second research question: "to what extent does the impact of perceived organizational support from the management company on employee commitment vary between employees recruited prior to and post the transfer?" Given that affective commitment involves value congruence between an individual and an organization, it is most likely that an individual's affective commitment will occur towards an organization to which the individual feels "cognitively closer" to (Mueller \& Lawler, 1999; Riketta \& Van Dick, 2005). In this case of separation between employment and management, the management company has direct contact with employees. Therefore, employees might be expected to feel cognitively closer to the management company. Consequently, the better the support the management company provides to employees, the more likely that the employees will demonstrate affective commitment to the management company. Consequently our second hypothesis:

$\mathrm{H}_{2}$ : The perceived organizational support from the management company positively influences employees' affective commitment to the management company. 
Whilst Hypothesis 2 complies with the reciprocity principle of social exchange theory, the limitation of the two-way exchange needs to be considered within the context of a long-term public-private partnership. Within this the transfer of employees' management represents the start of an ongoing three-way exchange where a management company works closely with the employing organization in the management of employees and the provision of services. Initially the relationship between the perceived organizational support from the management company and employees' affective commitment to the management company will be subject to employees' experiences and perceptions of the transfer process. Specifically, employees who perceived higher levels of procedural and interactional justice in the transfer process (hereafter 'Positive-Transfer Incumbents') are likely to be more positive towards the management company, and consequently develop a higher level of affective commitment, compared with those who perceived a lower level of organizational justice (hereafter 'Negative-Transfer Incumbents'). In contrast, the relationship between the perceived organizational support from the management company and affective commitment for employees who were recruited after the transfer process (hereafter 'Post-Transfer New-Starts') is unlikely to be influenced by the employee transfer process. Therefore, our third set of hypotheses is:

$\mathrm{H}_{3 \mathrm{a}}$ : The impact of the perceived organizational support from the management company on employees' affective commitment to the management company varies between Negative-Transfer Incumbents (with low perceived procedural justice), Positive-Transfer Incumbents (with high perceived procedural justice), and Post-Transfer New-Starts.

$\mathrm{H}_{3 \mathrm{~b}}$ : The impact of the perceived organizational support from the management company on employees' affective commitment to the management company 
varies between Negative-Transfer Incumbents (with low perceived interactional justice), Positive-Transfer Incumbents (with high perceived interactional justice), and Post-Transfer New-Starts.

Existing research indicates that continuance commitment is not associated in the same way as affective commitment with various antecedents of employee commitment (e.g. Allen \& Meyer, 1996; Meyer et al., 2002). Perceived organizational support lessens feelings of entrapment that develop when employees have no other choice but to continue working for the organization because of the high costs associated with leaving (Shore \& Tetrick, 1991; Rhodes \& Eisenberger, 2002). Consequently perceived organizational support, whilst increasing affective commitment, lowers continuance commitment (Aubé et al., 2007). Given this, it seems probable that the more positive employees perceive support from the management company, the less likely they are to feel entrapped in the organization. Therefore, our fourth hypothesis is:

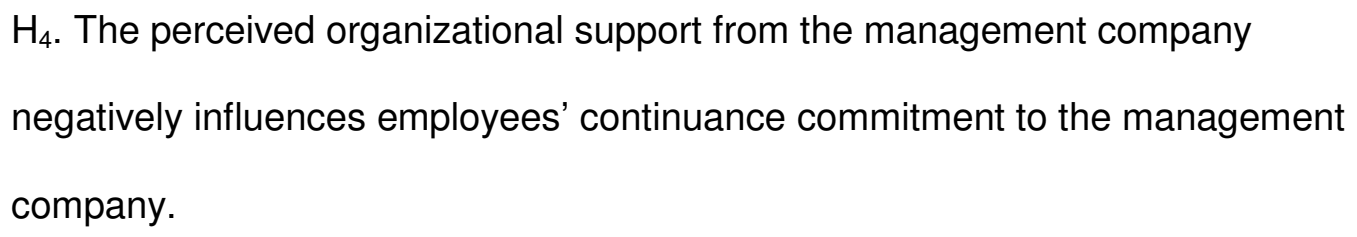
According to the two-way social exchange theory, continuance commitment is based on a calculation of the costs involved in leaving the organization as a single referent. In an employment relationship where the employing organization is separate from the management company, the inter-play among the two organizations and the employees needs to be taken into account. If employees perceive the transfer process was procedurally fair and their supervisors interactionally fair throughout the process, they are less likely to develop feelings of reluctance to continue to work with the management company. Therefore, the impact of the perceived organizational support 
from the management company on employees' continuance commitment to the management company needs to be considered in conjunction with perceived organizational justice in the employee transfer process. Consequently our final set of hypotheses is:

$\mathrm{H}_{5 \mathrm{a}}$ : The impact of the perceived organizational support from the management company on employees' continuance commitment to the management company varies between Negative-Transfer Incumbents (with low perceived procedural justice), Positive-Transfer Incumbents (with high perceived procedural justice) and Post-Transfer New-Starts.

$\mathrm{H}_{5 b}$ : The impact of the perceived organizational support from the management company on employees' continuance commitment to the management company varies between Negative-Transfer Incumbents (with low perceived interactional justice), Positive-Transfer Incumbents (with high perceived interactional justice) and Post-Transfer New-Starts.

\section{Method}

The research was conducted one year after the completion of the transfer process in an NHS hospital (hereafter 'the Hospital'), which had adopted the RoE model to contract out three facilities management departments: Portering, Catering, and Domestic. All employees up to the working supervisor level (the sampling frame of our study) had been seconded under the RoE model to the private partner (the management company), maintaining their contract of employment with the NHS. In contrast their managers had been transferred to the management company under the Transfer of Undertakings (Protection Employment) Regulations 1981. Subsequently 
the management company was also responsible for recruitment and management of new facilities management staff as NHS employees under the RoE model. At the time of the research, the number of employees on secondment was approximately 300 , of whom the Hospital estimated $60 \%$ was recruited directly by NHS before the transfer, the remaining $40 \%$ being recruited directly as NHS employees by the management company. These estimates were subsequently confirmed by the management company.

Data were collected using a questionnaire, the design of which was informed by semistructured interviews. These interviews were conducted with eight managers involved in the implementation and subsequent management of the RoE model. Three of these were employed by the NHS hospital and five by the management company, the latter including the three functional managers of the contracted-out facilities management departments. The interviews were designed to establish the organizational structure of the Hospital, the lines of responsibilities between the HR Departments of the Hospital and the management company, the managers' perceptions on the RoE transfer process, and the feedback that they received from the employees, thereby informing the design of the questionnaire.

The questionnaire comprised of 23 seven-point Likert style questions designed to collect data on respondents' perceptions of the transfer process, perceived organizational support and affective and continuance commitment (Appendix 1). Six additional questions collected demographic data (Table 1). Perceived procedural justice during the employee transfer process $(\alpha=0.74)$ was measured using three items. Two were adopted from Coyle-Shapiro et al.'s (2004) five item scale measuring the extent to which there were fair procedures for employees to appeal decision and have their own views heard; their remaining three items, relating to fairness of salary 
increase, performance evaluation and promotion were excluded as the interviews had highlighted that the RoE transfer process did not entail changes to these aspects. A third item "I was informed timely regarding the employee transfer process" was included as the interviews highlighted this was an important aspect of the RoE transfer procedure. Perceived interactional justice during the transfer process $(\alpha=0.85)$ consisted of the three items from Coyle-Shapiro et al.'s (2004) study adapted to measure the extent to which the supervisors treated everyone in a fair and consistent manner, and gave employees opportunities to express their own views during the RoE process.

Perceived organizational support from the management company was measured initially using nine items: eight from Eisenberger et al.'s (1986) scale and an additional item, derived from the interviews, to measure the sufficiency of training. However, Items 2 and 5 did not load well (with the item-total correlation below 0.4) and hence were excluded from further analyses. The final perceived organizational support construct consisted of seven items ( $\alpha=0.93)$ (see Appendix 1).

Affective commitment was measured by Shore et al.'s (1995) four item scale ( $\alpha=0.89)$, their term 'the employee' being replaced with 'l'. This is a validated short version of Meyer and Allen's (1984) scale, and measures the extent to which employees felt emotionally attached to the management company and genuinely cared about the fate of the organization. Continuance commitment $(\alpha=0.76)$ was measured similarly using an adaptation of Shore et al.'s (1995) four item scale for which one of the original items was split into two (Items 3 and 4, appendix 1) to overcome problems of misinterpretation revealed in pilot testing. This captured the extent to which employees felt obliged to stay with the management company, given the costs involved should they decide to leave. 
Following a pilot, the questionnaire was personally distributed and collected by the lead author during the monthly team briefings used to communicate HR policies of the Hospital and local issues to the staff. Eight team briefings were attended in the Domestic and Catering Departments, each consisting of five to 22 staff, over a twoweek period. The Portering Department did not organize formal team briefings, given the 'on-the-go' nature of portering tasks. Therefore, questionnaires were distributed and collected by the lead author at different shifts during the two-week period. A total of 114 questionnaires were returned. Deducting the 13 spoilt, 101 questionnaires were entered in the analysis; a $33 \%$ effective response rate.

Table 1 summarizes the profile of the sample (in terms of age, education, gender and nationality). Although the management company declined to provide equivalent data for all employees, HR Managers at the Hospital and the management company confirmed the profile was broadly comparable with that of the facilities management workforce. Moreover, among 101 respondents, 60 were recruited prior to the transfer, and 41 were recruited post the transfer; this is similar to the estimated $60: 40$ ratio of all employees recruited prior to and post the transfer, providing some evidence of the representativeness of our sample.

\section{Place Table 1 about here}

Statistical analyses utilized Pearson's correlation and regression analysis, taking the sample size into consideration. To check the potential problem of multicollinearity, a range of indicators including variance proportions, condition indexes, variance inflation factor and tolerance level were examined (Belsley, 1991; Chatterjee et al., 2000). In all multivariate regression models, there was no evidence of two or more variables having 
large proportions of variance (i.e. 0.5 or more) that corresponded to a large condition index; the tolerance levels were close to 1 ; and the variance inflation factors were also small (close to 1). Hence, there was no evidence of multicollinearity.

Our study is based on self-reported data and hence is subject to the scrutiny of common method variance (Podsakoff et al., 2003). While some researchers caution the potential problem of common method bias (e.g. Williams et al., 1989), other scholars suggest that the inflation of relationships based on self-reported data may be overestimated (Crampton \& Wagner, 1994; Spector, 1987). Following the conventional approach of examining common method variance, the Harman's one-factor test (Podskoff \& Organ, 1986) was conducted, entering all dependent and independent variables in our study into an exploratory factor analysis. The results showed that no single factor emerged, nor was there a general factor which could account for the majority of the variance in these variables. The first factor accounted for only $38.2 \%$ of the total variance. Therefore, common methods bias is not a major problem in this study.

\section{Research Findings}

\subsection{The transfer process and perceived organizational support}

Our first research question is concerned with the extent to which employees' perceptions of their treatment in the transfer process were associated with the perceived organizational support from the management company. The results of the Pearson's correlation (Table 2) show that, among employees who experienced the RoE transfer process, perceived procedural $(r=0.26, p<0.05)$ and interactional justice $(r=0.57, \mathrm{p}<0.01)$ in the employee transfer process were positively correlated with perceived organizational support from the management company. The findings support 
$\mathrm{H}_{1 \mathrm{a}}$ and $\mathrm{H}_{1 \mathrm{~b}}$ : perceived procedural and interactional justice during the transfer process were positively associated with employees' perceived organizational support from the management company. Moreover, it is worth noting that, the correlation coefficient for interactional justice was stronger than for procedural justice.

\section{Place Table 2 about here}

To further explore this relationship, we grouped employees who experienced the RoE process into two categories based on their perceptions of procedural justice: 'NegativeTransfer Incumbents' (those employees who perceived a low level of procedural justice in the transfer process with a value equal to or below the mean, 3.54); and 'PositiveTransfer Incumbents' (those who perceived a higher level of procedural justice with a value above the mean). Both groups were compared with a third group - 'Post-Transfer New-Starts' (those employees who did not directly experience the transfer process, as they were recruited after the transfer process, but under the same employment conditions). The three groups were compared regarding their perceived organizational support from the management company using Analysis of Variance (ANOVA) test, resulting in mean scores of 3.21 for Negative-Transfer Incumbents, 3.93 for PositiveTransfer Incumbents, and 3.83 for Post-Transfer New-Starts. The results indicate that although there was some differences between the three groups, these were statistically insignificant ( $F=1.49$, n.s.).

Employees were then grouped into two categories based on their perceptions of interactional justice: Negative-Transfer Incumbents (those employees who perceived a lower level of interactional justice in the transfer process with a value equal to or below the mean, 4.56); and Positive-Transfer Incumbents (those who perceived a higher level of procedural justice with a value above the mean). Both groups were compared with 
Post-Transfer New-Starts on perceived organizational support. The results of ANOVA showed that the mean score of perceived organizational support for Negative-Transfer Incumbents (2.92) was significantly lower than those of Positive-Transfer Incumbents (3.83) and Post-Transfer New-Starts (4.19) $(F=4.30, \mathrm{p}<0.02)$.

\subsection{Perceived organizational support and commitment}

Our second research question is concerned with the extent the impact of the perceived organizational support from the management company on employee commitment varies between employees recruited prior to and post the transfer as expressed by hypotheses two through five. To test $\mathrm{H}_{2}$, perceived organizational support from the management company as the independent variable and affective commitment to the management company as the dependent variable, were entered in a regression analysis together with three control variables: gender, nationality and contract term. The results show that gender did not have a significant effect on affective commitment, whilst the effects of the latter two control variables were significant (Table 3). Specifically, permanent contract holders were less likely to demonstrate affective commitment to the management company than other contract holders $(\beta=-0.24, t=-$ 3.26, $p<0.002)$; and UK nationals were less likely to demonstrate affective commitment to the management company than those from overseas $(\beta=-0.29, t=-3.85, p<0.001)$. Furthermore, perceived organizational support from the management company had a significant, positive effect on affective commitment to the management company ( $\beta=$ $0.61, t=7.73, p<0.001)$. The overall model statistics were also significant $\left(R^{2}=0.50\right.$, adjusted $\left.R^{2}=0.48, F=23.58, p<0.001\right)$. Therefore, $\mathrm{H}_{2}$ was supported: the perceived organizational support from the management company positively influences employees' affective commitment to the management company. 
$\mathrm{H}_{3 a}$ was tested by performing regression analysis with perceived organizational support as the independent variable, affective commitment as the dependent variable and the employee grouping as the selection variable. The standardized regression coefficients for Negative-Transfer Incumbents (with low perceived procedural justice), PositiveTransfer Incumbents (with high perceived procedural justice), and Post-Transfer NewStarts were $0.45(t=2.54, p<0.02), 0.62(t=3.99, p<0.001)$ and $0.67(t=5.60, p<0.001)$, respectively (Table 3). This indicated that the relationship, although statistically significant, varied between all three groups. Therefore, $\mathrm{H}_{3 a}$ was accepted. $\mathrm{H}_{3 b}$ was tested using the same approach, except that the employee grouping was based on the perceived interactional justice. The results showed that the standardized regression coefficients for Negative-Transfer Incumbents (with low perceived interactional justice), Positive-Transfer Incumbents (with high perceived interactional justice), and PostTransfer New-Starts were 0.35 ( $t=1.85$, n.s.), $0.58(t=3.71, p<0.001)$ and $0.67(t=5.60$, $p<0.001$ ), respectively (Table 3 ). This indicated that the impact of perceived organizational support on affective commitment varied between the three groups, and the discerned relationship among Negative-Transfer incumbents was statistically insignificant. Therefore, $\mathrm{H}_{3 b}$ was accepted.

To test $\mathrm{H}_{4}$, perceived organizational support from the management company as the independent variable and continuance commitment as the dependent variable were entered in a regression analysis together with three control variables (gender, nationality and contract term). The standardized regression coefficients for the three control variables indicated that none was statistically significant (Table 3), but the impact of the perceived organizational support on continuance commitment was positive and statistically significant $(\beta=0.35, t=3.45, p<0.001)$. These results contradict $\mathrm{H}_{4}$ and, therefore, $\mathrm{H}_{4}$ is rejected. 
Following similar procedures of testing $\mathrm{H}_{3 a}$ and $\mathrm{H}_{3 b}$, the results of $\mathrm{H}_{5 \mathrm{a}}$ show that the standardized regression coefficients from perceived organizational support to continuance commitment for the Negative-Transfer Incumbents (with low perceived procedural justice), Positive-Transfer Incumbents (with high perceived procedural justice) and Post-Transfer New-Starts were 0.27 ( $t=1.43$, n.s.), $0.44(t=2.42, p<0.05)$ and $0.42(\mathrm{t}=2.92, \mathrm{p}<0.01)$, respectively (Table 3$)$. The impact of perceived organizational support on continuance commitment was weak and insignificant among Negative-Transfer Incumbents, whilst the relationship was stronger and significant for the other two groups. Similarly, the results of $\mathrm{H}_{5 b}$ showed that the impact of organizational support from the management company on employees' continuance commitment to the management company also varied: Negative-Transfer Incumbents ( $\beta=-0.03, t=-0.15, n . s$.$) had a low and insignificant regression coefficient compared with$ the Positive-Transfer Incumbents $(\beta=0.49, t=2.93, p<0.01)$ and Post-Transfer NewStarts $(\beta=0.42, t=2.92, p<0.01)$. Therefore, $\mathrm{H}_{5 \mathrm{a}}$ and $\mathrm{H}_{5 \mathrm{a}}$ are supported: the impact of the perceived organizational support from the management company on employees' continuance commitment to the management company varies in degree between the three groups (Table 3).

\section{Place Table 3 about here}

\section{Discussion}

We set out to investigate two questions pertinent to employee commitment in a new form of employment relationship in the context of a PFI project in an NHS hospital. The findings have implications for theory, practice and future research. 


\subsection{Theoretical implications}

Firstly, and in answer to our first research question, our findings suggest that in a new form of employment relationship which involves the transfer of employees' management from one organization (the employing organization) to another (the management company), employees' perceptions of the procedural and interactional justice of the transfer process itself influence their perceptions of the management company. In particular, perceived interactional justice had a stronger association with the perceived organizational support from the management company, compared with perceived procedural justice. In the RoE model supervisors in the Hospital were transferred under the same conditions as employees in their teams. This meant employees had some sense of certainty and familiarity within their workplace and hence the stronger impact of interactional justice. Further analysis in answer to our second question suggests that the subsequent impact of employees' experience of the transfer process is far reaching. Positive-Transfer Incumbents (with high perceived procedural or interactional justice) and Post-Transfer New-Starts were most likely to positively respond to the perceived organizational support provided by the management company, which in turn leads to increased (particularly affective) commitment to the management company (see Table 3). In contrast for NegativeTransfer Incumbents (with low perceived interactional justice), their perceived organizational support from the management company did not necessarily lead to affective commitment.

Secondly, the findings suggest that the conventional social exchange theory that emphasizes a two-way reciprocity between the employer and the employee (Shore and Wayne, 1993; Herriot et al., 1997) needs to be re-examined to take into consideration the complex inter-play among various parties involved in new forms of employment relationship. An effective employment relationship often involves the employing and 
the management organizations working closely together. Although Coyle-Shapiro et al. (2006) touched on the importance of communicating the information about the client organization to the employees, this issue was not addressed explicitly. Our research provides clear evidence accentuating the importance of fairness and justice (particularly the interactional justice) during the employee transfer process and its effect on employees' perceptions of, and commitment to, the management company. The findings mirror the predication that new organizational forms, such as the secondment of employees to a management company in our study context, have brought about unexpected changes (Kessler et al., 2004). If handled inappropriately, such unexpected change may lead to a loss of employee (particularly affective) commitment (Herriot et al., 1997; Guzzo et al., 1994). This suggests that nurturing employees' affective commitment to the management company needs to go beyond perceived organizational support from the management company, and calls for joint effort between the employing and the management organizations.

Thirdly, this study focused on the management company as the referent of employment commitment, which has been under-researched in the existing literature. Although empirical research generally concurs that perceived organizational support positively affects employee commitment (Eisenberger et al., 1986), very few studies have focused on a referent organization other than the employing organization. The few exceptions include Liden et al. (2003) and Coyle-Shapiro et al. (2006), who found a positive relationship between perceived organizational support from the client company and affective commitment to the client company in the context of agency and long-term contract employees. Our findings provide further empirical evidence of this relationship in the context of PFI projects in the NHS sector. 
Finally and in answer to our second research question, our findings suggest that perceived organizational support from the management company had a positive, significant effect on continuance commitment to the management company, particularly among Positive-Transfer Incumbents and Post-Transfer New-Starts (see Table 3). These results appear to contradict existing research, which found negative to zero effect between perceived organizational support and continuance commitment (Shore \& Tetrick, 1991; Rhoades \& Eisenberger, 2002; Aubé et al., 2007). One possible explanation lies in the nature of the job profile of our respondents (i.e. catering, portering and domestic services). These employees are less equipped with skills to manage risks in the private sector (Sussex, 2002), and hence their perceived costs of leaving are high. Although arguably perceived organizational support may lower continuance commitment, whilst increasing affective commitment (Aubé et al., 2007), the reduction of continuance commitment may require other conditions, such as job enrichment and skill mobility. For the respondents of this study, their lower skills and lack of formal education and the labour-intensive nature of their work mean that the reduction of continuance commitment is less likely. Consequently, the findings suggest that the theory of continuance commitment must take into account the job nature and the skill profile of the employees concerned.

\subsection{Practical implications}

Our findings have an important managerial implication with regard to employee commitment and job performance in an atypical employment relationship, such as PFI projects. $\mathrm{PFI}$ is intended to promote long-term public-private partnership, requiring the two organizations to work together. In particular, early interaction between the management company and employees is likely to decrease the uncertainty perceived by the employees and ease unnecessary anxiety in the transfer process. The effect of the transfer process appears far reaching: the perceived procedural and interactional 
fairness of the transfer process influence the employees' perceptions of the level of support from the management company, which in turn influence employees' affective commitment to the management company. Within this, the role of supervisors is of considerable importance, their interaction with employees having a strong influence on employees' attitudes and behaviour.

\subsection{Limitations and future research agenda}

Despite the above contributions, this study has several limitations. Firstly, we chose to systematically examine employee commitment to the management company, but point out that future research may investigate the different foci of commitment (Redman \& Snape, 2005; Becker, 1992; Becker et al., 1996), which may shed further light on new forms of employment relationship. Furthermore, although our research is informed by the social exchange theory, like Kessler et al. (2004), we do not explicitly examine the changes in the psychological contract, but rather are informed by the underlying influence of the psychological contract in employee attitudes and behaviour. Future research may include these important concepts to illuminate the impact of the RoE transfer process on employee attitudes and behaviour.

Secondly, there is a trade-off between a research design that focuses on uniqueness and one that favours generalizability. The focus of this study on RoE employees in the NHS hospital provides unique insights on the employee commitment in this new organizational arrangement. Inevitably this limited our sampling frame. Consequently, the effective sample size of this study does not warrant the use of confirmatory factor analysis and structural equation modeling. Future research may gather a larger dataset across different organizations to simultaneously test the relationships in our model using structural equation modeling to provide generalized understanding. 
Finally, this study was undertaken one year after the completion of the RoE transfer process. Although our findings indicated that the impact of RoE transfer was still significant at this time, such an effect is expected to diminish in the future, as the sense of uncertainty and insecurity weakens. Moreover, Coyle-Shapiro et al. (2006) suggest that employees distinguish between sources of support, perceptions of which form the basis of their commitment to the relevant foci. If the management company offers improved organizational support (including team briefings and training), employees are likely to form positive views of the management company. As time goes on, the difference of affective commitment between employees recruited prior to and post the transfer is also expected to diminish over time. Therefore, a longitudinal study of the links amongst perceived organizational support, employee commitment, and organizational citizenship behaviour would provide further insights.

\section{Conclusion}

Employee commitment research has taken on a new dimension in the era of new organizational forms. Although this study focuses on a unique employment relationship entailed in a PFI project in an NHS hospital, the findings highlight that, in the case of separation between the employing organization and management company, both parties must work in partnership to enable a smooth employee transfer process. Perceived procedural and interactional justice in the transfer process is positively associated with perceived organizational support from the management company. Furthermore, employees' (lack of) experience of the transfer process may also be an influential factor when employee commitment to the management company is concerned. The findings contribute to the social exchange theory, which underpins the employee commitment research, by stressing that resource exchange must be examined beyond the conventional two-way reciprocity to account for the inter-play 
among multiple stakeholders. The findings also have practical implications for managers to effectively manage the employee transfer process and work in partnership in order to nurture employees' affective commitment.

\section{References:}

Allen, G. (2001), The Private Finance Initiative (PFI). Research Paper 01/117, $18^{\text {th }}$ December. Economic Policy and Statistics Section House of Commons Library.

Allen, N. J. \& Meyer, J. P. (1990), "The measurement and antecedents of affective, continuance and normative commitment to the organization", Journal of Occupational Psychology, Vol. 63, pp.1-18.

Allen, N.J. \& Meyer, J.P. (1996), "Affective, continuance, and normative commitment to the organization: an examination of construct validity", Journal of Vocational Behaviour, Vol. 49 No. 3, pp. 252-76.

Aubé, C., Rousseau, V. \& Morin, E. M. (2007), "Perceived organizational support and organizational commitment: the moderating effect of locus of control and work autonomy", Journal of Managerial Psychology, Vol. 22, pp.479-495.

Becker, T. E. (1992), "Foci and bases of commitment: are the distinctions worth making?" Academy of Management Journal, Vol. 35, pp.232-244.

Becker, T. E., Billings, R. S., Eveleth, D. M., \& Gilbert, N. L. (1996), "Foci and bases of employee commitment: implications for job performance", Academy of Management Journal, Vol.39, pp.464-482.

Belsley, D. A. (1991), Conditioning Diagnostics, Collinearity and Weak Data in Regression ( $1^{\text {st }}$ edition). New York, NY: John Wiley and Sons, Inc.

Benson, J. (1998) "Dual commitment: Contract workers in Australian manufacturing enterprises", Journal of Management Studies Vol. 33, pp. 355-375.

Bies, R.J. \& Moag, J.S. (1986), "Interactional Justice: Communication Criteria for Fairness". In R. Lewicki, B. Sheppard \& M. Bazerman (eds.) Research on Negotiation in Organizations, Greenwich, CT: JAI Press, pp. 43-55.

Bies, R.J. (2006), "Are procedural and interactional justice conceptually distinct?" In J Greenberg and J Colquitt (eds.) Handbook of Organizational Justice, pp.85-112.

Biggs, D. \& Swailes, S. (2005), "Relations, commitment and satisfaction in agency workers and permanent workers", Employee Relations, Vol.28 pp.130-143.

Bowen, D. E. \& Ostroff, C. (2004), "Understanding HRM-firm performance linkages: the role of the "strength" of the HRM system". Academy of Management Review, Vol. 29, pp.203-221. 
Carrol, M., Cooke, F. L. \& Hebson, G. (2005), "Commitment and identity across organisational boundaries". In Marchington, M., Grimshaw, D., Rubery, J. \& Wilmott, H. (Eds), Fragmenting Work: Blurring Organisational Boundaries and Disordering Hierarchies. Oxford University Press, Oxford, pp.179-198.

Chatterjee, S., Hadi, A. S. \& Price, B. (2000), Regression Analysis by Example (3 $3^{\text {rd }}$ edition). New York, NY: John Wiley and Sons, Inc.

Clatworthy, M. A., Mellett, H. J. \& Peel, M. J. (2000), "Corporate governance under 'New Public Management': an exemplification”. Corporate Governance, Vol. 8, pp.166-176.

Cohen-Carash, Y. \& Spector, P.E. (2001), "The role of justice in organizations: a metaanalysis", Organizational Behaviour and Human Decision Processes, Vol. 86, pp.278-324.

Colquitt, J.A. (2001), "On the dimensionality of organizational justice: a construct validation of a measure", Journal of Applied Psychology, Vol. 86, pp.386-400.

Colquitt, J.A., Greenberg, J. \& Zapta-Phelan, C.P. (2006), "What is organizational justice? a historical overview", In J Greenberg \& J Colquitt (eds.) Handbook of Organizational Justice, pp. 3-56.

Coyle-Shapiro, J. A-M. \& Morrow, P. C. (2006), "Organizational and client commitment among contracted employees", Journal of Vocational Behaviour, Vol. 68, pp.416431.

Coyle-Shapiro, J. A-M., Kessler, I. \& Purcell, J. (2004), "Exploring organizationally directed citizenship behaviour: reciprocity or "it's my job?" Journal of Management Studies, Vol. 41, pp.85-106.

Coyle-Shapiro, J. A-M., Marrow, P. C. \& Kessler, I. (2006), "Serving two organizations: Exploring the employment relationship of contracted employees", Human Resource Management, Vol. 45, pp.561-583.

Crampton, S. M. \& Wagner, J. A. (1994), "Percept-percept inflation in micro organizational research: An investigation of prevalence and effect", Journal of Applied Psychology, Vol. 79, pp.67-76.

Cropanzano, R. \& Greenberg, J. (1997), "Progress in organizational justice: tunnelling through the maze', In C.L. Cooper \& I.T. Robertson (Eds.), International Review of Industrial and Organizational Psychology, Vol.12, pp.243-298. Chichester: Wiley.

Dunham, R. B., Grube, J. A. \& Castaneda, M. B. (1994). "Organizational commitment: the utility of an integrative definition". Journal of Applied Psychology, Vol. 79, pp.370-380.

Eisenberger, R., Huntington, R., Hutchison, S. \& Sowa, D. (1986), "Perceived organizational support”, Journal of Applied Psychology, Vol. 71, pp.500-507. 
Ezzamel, M. \& Willmott, H. (1993), "Corporate governance and financial accountability: recent reforms in the UK public sector", Accounting, Auditing and Accountability Journal, Vol. 6, pp.109-132.

Felfe, J., Yan, W., \& Six, B. (2008), "The impact of individual collectivism on commitment and its influence on OCB, turnover, and strain in three countries", International Journal of Cross-Cultural Management, Vol. 8, pp.211-237.

Gallagher, D. G. \& McLean Parks, J. (2001), "I pledge thee my troth...contingently: commitment and the contingent work relationship", Human Resource Management Review, Vol. 11, pp.181-208.

Gautam, T., Van Dick, R. \& Wagner, U. (2004). "Organizational identification and organizational commitment: distinct aspects of two related concepts". Asian Journal of Social Psychology, Vol. 7, pp.301-315.

Greenberg, J. (1993), "The social side of fairness: interpersonal and informational classes of organizational justice", In R. Cropanzano (Ed.), Justice in the Workplace: Approaching Fairness in Human Resource Management. Hillsdale, NJ: Erlbaum, pp. 79-103.

Guzzo, R. A., Noonan, K. A. \& Elron, E. (1994), "Expatriate managers and the psychological contract”, Journal of Applied Psychology, Vol. 79, pp.617-626.

Herriot, P., Manning, W. E. G. \& Kidd, J. M. (1997), "The content of psychological contract”, British Journal of Management, Vol. 8, pp.151-162.

Hood, C. (1991), "A public management for all seasons", Public Administration, Vol. 69, pp.3-19.

Ismail, S. \& Pendlebury, M. (2006), "The Private Finance Initiative (PFI) in schools: the experiences of users", Financial Accountability \& Management, Vol. 22, pp.381404.

Kernan, M.C. \& Hanges, P.J. (2002), "Survivor reactions to reorganization: antecedents and consequences of procedural, interpersonal, and informational justice", Journal of Applied Psychology, Vol. 87, pp.916-28.

Kessler, I., Coyle-Shapiro, J. \& Purcell, J. (2004), "Outsourcing and the employee perspective", Human Resource Management Journal, Vol. 9, pp.5-19.

Kinnie, N., Hutchinson, S., Purcell, J., Rayton, B. \& Swart, J. (2005), "Satisfaction with HR practices and commitment to the organisation: why one size does not fit all", Human Resource Management Journal, Vol.15, pp.9-29.

Leventhal, G.S. (1976), "Fairness in Social Relationships", In Thibaut, J.W., Spence, J.T. \& Carson, R.C. (Eds.), Contemporary Topics in Social Psychology, Morristown, NJ: General Learning Press, pp. 211-239.

Liden, R. C., Wayne, S. J., Kraimer, M. L. \& Sparrowe, R. T. (2003), "The dual commitments of contingent workers: an examination of contingents' commitment to the agency and the organization", Journal of Organizational Behaviour, Vol. 24, pp.609-635. 
Loi, R., Hang-Yue, N. \& Foley, S. (2006), "Linking employees' justice perceptions to organizational commitment and intention to leave: the mediating role of perceived organizational support", Journal of Occupational and Organizational Psychology, Vol. 79, pp.101-120.

Meyer, J. P. \& Allen, N. J. (1984), "Testing the "Side-Bet Theory" of organizational commitment: some methodological considerations", Journal of Applied Psychology, Vol. 69, pp.372-378.

Meyer, J. P. \& Allen, N. J. (1991), "A three-component conceptualization of organizational commitment", Human Resource Management Review, Vol. 1, pp.61-89.

Meyer, J. P. \& Allen, N. J. (1997), Commitment in the Workplace: Theory, Research and Application. Thousand Oaks, CA: Sage.

Meyer, J. P., Stanley, D. J., Herscovitch, L. \& Topolnytsky, L. (2002), “Affective, continuance and normative commitment to the organization: a meta-analysis of antecedents, correlates, and consequences", Journal of Vocational Behaviour, Vol. 61, pp.20-52.

Moideenkutty, U., Blau, G., Kumar, R. \& Nalakath, A. (2001), "Perceived organizational support as a mediator of the relationship of perceived situational factors to affective organizational commitment", Applied Psychology: An International Review, Vol. 50, pp.615-634.

Morrow, P. C. (1993), The Theory and Measurement of Work Commitment. Greenwich, NJ: JAI Press.

Mowday, R. T., Steers, R.M. \& Porter, L. W. (1979), "The measurement of organizational commitment”, Journal of Vocational Behaviour, Vol. 14, pp.224247.

Mueller, C. W. \& Lawler, E. J. (1999), "Commitment to nested organizational units: some basic principles and preliminary findings", Social Psychology Quarterly, Vol.62, pp.325-346.

Podsakoff, P.M. \& Organ, D. W. (1986), "Self-reports in organizational research: problems and prospects", Journal of Management, Vol.12, pp.531-544.

Podsakoff, P. M., MacKenzie, S.B., Lee, J.Y. \& Podsakoff, N.P. (2003), Common method bias in behavioral research: a critical review of the literature and recommended remedies", Journal of Applied Psychology, Vol. 88, pp.879-903.

Prowle, M. (2006), The Role of The Private Finance Initiative in the Delivery of Health Services in the UK. Technical Approach Paper. HLSP Institute, 5-23 Old Street, London, EC1V 9HL, UK.

Redman, T. \& Snape, E. (2005), "Unpacking commitment: multiple loyalties and employee behaviour", Journal of Management Studies, Vol.42, pp.301-328.

Rhoades, L. \& Eisenberger, R. (2002), "Perceived organization support: a review of the literature", Journal of Applied Psychology, Vol.87, pp.698-714. 
Riketta, M. \& Van Dick, R. (2005), "Foci of attachment in organizations: a metaanalytic comparison of the strength and correlates of workgroup versus organizational identification and commitment", Journal of Vocational Behaviour, Vol.67, pp.490-510.

Rousseau, D. M. (1990), "New hire perceptions of their own and their employer's obligations: a study of psychological contracts", Journal of Organisational Behaviour, Vol.11, pp.389-400.

Rousseau, D. M. (2001), « Schema, promise and mutuality : the building blocks of the psychological contract", Journal of Occupational and Organizational Psychology, Vol.74, pp.511-541.

Rubery, J., Earnshaw, J., Marchington, M., Cooke, F. L. \& Vincent, S. (2002), "Changing organizational forms and the employment relationship", Journal of Management Studies, Vol.39, pp.645-672.

Saunders, M.N.K. \& Thornhill, A. (2004), "Trust and mistrust in organisations: an exploration using an organisational justice framework", European Journal of Work and Organisational Psychology, Vol. 13, pp.492-515

Shore, L. \& Tetrick, L. (1991), "A construct validity study of the survey of perceived organizational support”, Journal of Applied Psychology, Vol.76, pp.637-643.

Shore, L. M. \& Wayne, S. J. (1993), "Commitment and employee behaviour: comparison of affective commitment and continuance commitment with perceived organizational support", Journal of Applied Psychology, Vol.78, pp.774-780.

Shore, L. M., Barksdale, K. \& Shore, T. H. (1995), "Managerial perceptions of employee commitment to the organization", Academy of Management Journal, Vol.38, pp.1593-1615.

Spector, P.E. (1987), "Method variance as an artifact in self-reported affect and perceptions at work: myth or significant problem?" Journal of Applied Psychology, Vol. 72 No 3, pp.438-443.

Sullivan, H. \& Skelcher, C. (2002), Working Across Boundaries: Collaboration in Public Services. Palgrave Mcmillan, Basingstoke, Hampshire.

Sussex, J. (2002), Making the Best of the Private Finance Initiative in the NHS. Seminar Briefing no 4.Office of Health Economics.

Swailes, S. (2002), "Organizational commitment: a critique of the construct and measures", International Journal of Management Reviews, Vol.4, No.155-178.

Thibaut, J. \& Walker, L. (1975), Procedural Justice, Hillsdale, N J: Erlbaum.

Thornhill, A. \& Saunders, M.N.K. (2003). "Exploring employees' reactions to strategic change over time: the utilisation of an organisational justice perspective", Irish Journal of Management, Vol. 24, pp.66-86. 
Van Breugel, G., Van Olffen, W. \& Olie, R. (2005), "Temporary liaisons: the commitment of 'temps' towards their agencies", Journal of Management Studies, Vol. 42, pp.539-566.

Van Dyne, L., Graham, J. \& Dienesch, R. (1994), "Organizational citizenship behaviour: construct redefinition, measurement and validation", Academy of Management Journal, Vol. 37, pp.765-802.

Walsh, J. \& Deery, S. (2006), "Refashioning organizational boundaries: outsourcing customer service work", Journal of Management Studies, Vol.43, pp.557-582.

Williams, L.J., Cote, J.A. \& Buckley, M.R. (1989), "Lack of method variance in selfreport affect and perceptions at work: reality or artifact?" Journal of Applied Psychology, Vol. 74 No. 3, pp.462-468. 


\section{Appendix 1. The Measurement Scales}

\begin{tabular}{|c|c|c|}
\hline Constructs & Items & Sources \\
\hline $\begin{array}{l}\text { Perceived } \\
\text { procedural } \\
\text { justice }\end{array}$ & $\begin{array}{l}\text { The following questions are related to your view about the employee transfer process from the NHS to } \\
\text { the management company. } \\
\text { 1. There were fair procedures that I could use to appeal decisions that affected me. } \\
\text { 2. There were fair procedures that I could use to ensure that my views were heard in decisions that } \\
\text { affected me. } \\
\text { 3. I was informed timely regarding the employee transfer process. }\end{array}$ & $\begin{array}{l}\text { The first two items were } \\
\text { adopted from Coyle- } \\
\text { Shapiro et al. (2004). The } \\
\text { last item was added } \\
\text { based on the interviews. }\end{array}$ \\
\hline $\begin{array}{l}\text { Perceived } \\
\text { interactional } \\
\text { justice }\end{array}$ & $\begin{array}{l}\text { The following questions are related to your view about the employee transfer process from the NHS to } \\
\text { the management company. } \\
\text { 1. My supervisor gave me an opportunity to express my views. } \\
\text { 2. My supervisor was fair in his/her dealings with me. } \\
\text { 3. My supervisor treated everyone in a fair and consistent manner. }\end{array}$ & $\begin{array}{l}\text { Adapted from Coyle- } \\
\text { Shapiro et al. (2004). }\end{array}$ \\
\hline $\begin{array}{l}\text { Perceived } \\
\text { organizational } \\
\text { support }\end{array}$ & $\begin{array}{l}\text { The following questions are related to your view about the Partner after the employee transfer process. } \\
\text { 1. I feel that the management company cares about my general satisfaction at work. } \\
\text { 2. I feel that the management company fails to appreciate an extra effort from me*. } \\
\text { 3. I feel that the management company values my contributions to its well-being. } \\
\text { 4. I feel that the management company is willing to help me when I need personal assistance. } \\
\text { 5. I feel that the management company shows very little concern for me*. } \\
\text { 6. I feel that the management company tries to make my job as interesting as possible. } \\
\text { 7. I feel that the management company strongly considers my goals and values. } \\
\text { 8. Help is available from the management company when I have a problem. } \\
\text { 9. I feel that the management company provides sufficient support (such as training) for my personal } \\
\text { development. }\end{array}$ & $\begin{array}{l}\text { Items 1-8 were adapted } \\
\text { from Eisenberger et al. } \\
\text { (1986). The last item was } \\
\text { added based on the } \\
\text { interviews. }\end{array}$ \\
\hline $\begin{array}{l}\text { Affective } \\
\text { commitment }\end{array}$ & $\begin{array}{l}\text { 1. I am committed to the management company. } \\
\text { 2. I am emotionally attached to the management company. } \\
\text { 3. I view the management company's problems as my own. } \\
\text { 4. I care about the fate of the management company. }\end{array}$ & $\begin{array}{l}\text { Adapted from Shore et } \\
\text { al.'s (1995) scale which } \\
\text { was originally based on } \\
\text { Meyer and Allen (1984). }\end{array}$ \\
\hline $\begin{array}{l}\text { Continuance } \\
\text { commitment }\end{array}$ & $\begin{array}{l}\text { 1. I have too few options to consider leaving the management company. } \\
\text { 2. I stay with the management company as a matter of need. } \\
\text { 3. I continue working for the management company because leaving would require considerable } \\
\text { personal sacrifice. } \\
\text { 4. I continue working for the management company because another organisation may not match the } \\
\text { overall benefits that I have got here. } \\
\text { 5. I would find it hard to leave the management company even if I wanted to. }\end{array}$ & $\begin{array}{l}\text { Adapted from Shore et } \\
\text { al.'s (1995) scale which } \\
\text { was originally based on } \\
\text { Meyer and Allen (1984). }\end{array}$ \\
\hline
\end{tabular}


Table 1. The Profile of the Respondents

\begin{tabular}{lrcr}
\hline Age: & & Qualification: & \\
Below 22 & $9.9 \%$ & No qualification & $6.9 \%$ \\
$22-30$ & $44.6 \%$ & GCSE & $20.8 \%$ \\
$31-40$ & $22.8 \%$ & A' Level & $28.7 \%$ \\
$41-50$ & $16.8 \%$ & Bachelor/Master & $11.9 \%$ \\
Over 50 & $6.0 \%$ & Other & $31.7 \%$ \\
Nationality: & & Department: & \\
UK & $39.6 \%$ & Domestic & $55.4 \%$ \\
Overseas & $57.3 \%$ & Catering & $23.8 \%$ \\
Missing value & $3.1 \%$ & Portering & $20.8 \%$ \\
& & & \\
Gender: & & Contract type: & \\
Male & $58 \%$ & Permanent & $80.2 \%$ \\
Female & $42 \%$ & Other & $19.8 \%$ \\
\hline
\end{tabular}


Table 2. Descriptive Statistics

\begin{tabular}{|c|c|c|c|c|c|c|c|}
\hline & Mean & $\begin{array}{l}\text { Standard } \\
\text { deviation }\end{array}$ & $\alpha$ & 1 & 2 & 3 & 4 \\
\hline 1. Perceived procedural justice during the transfer & 3.81 & 1.71 & 0.74 & - & & & \\
\hline 2. Perceived interactional justice during the transfer & 4.56 & 1.89 & 0.85 & $0.57^{\star *}$ & - & & \\
\hline 3. Perceived organizational support & 3.64 & 1.64 & 0.93 & $0.26^{*}$ & $0.40^{* *}$ & - & \\
\hline 4. Affective commitment to the management company & 3.64 & 1.82 & 0.89 & $0.43^{\star *}$ & $0.42^{* *}$ & $0.66^{\star *}$ & - \\
\hline 5. Continuance commitment to the management company & 3.79 & 1.52 & 0.76 & 0.11 & $0.27^{\star}$ & $0.40^{\text {** }}$ & $0.38^{* *}$ \\
\hline
\end{tabular}

Notes: (1) Figures in the lower diagonal are correlation coefficients. The correlation coefficients related to perceived procedural and interactional justice are based only on the responses of employees who experienced the RoE process $(n=60)$, while the remaining coefficients are based on the whole sample $(n=101)$. (2) ${ }^{* *}$ correlation is significant at the 0.01 level. * correlation is significant at 0.05 level. 
Table 3. Analyses and Results

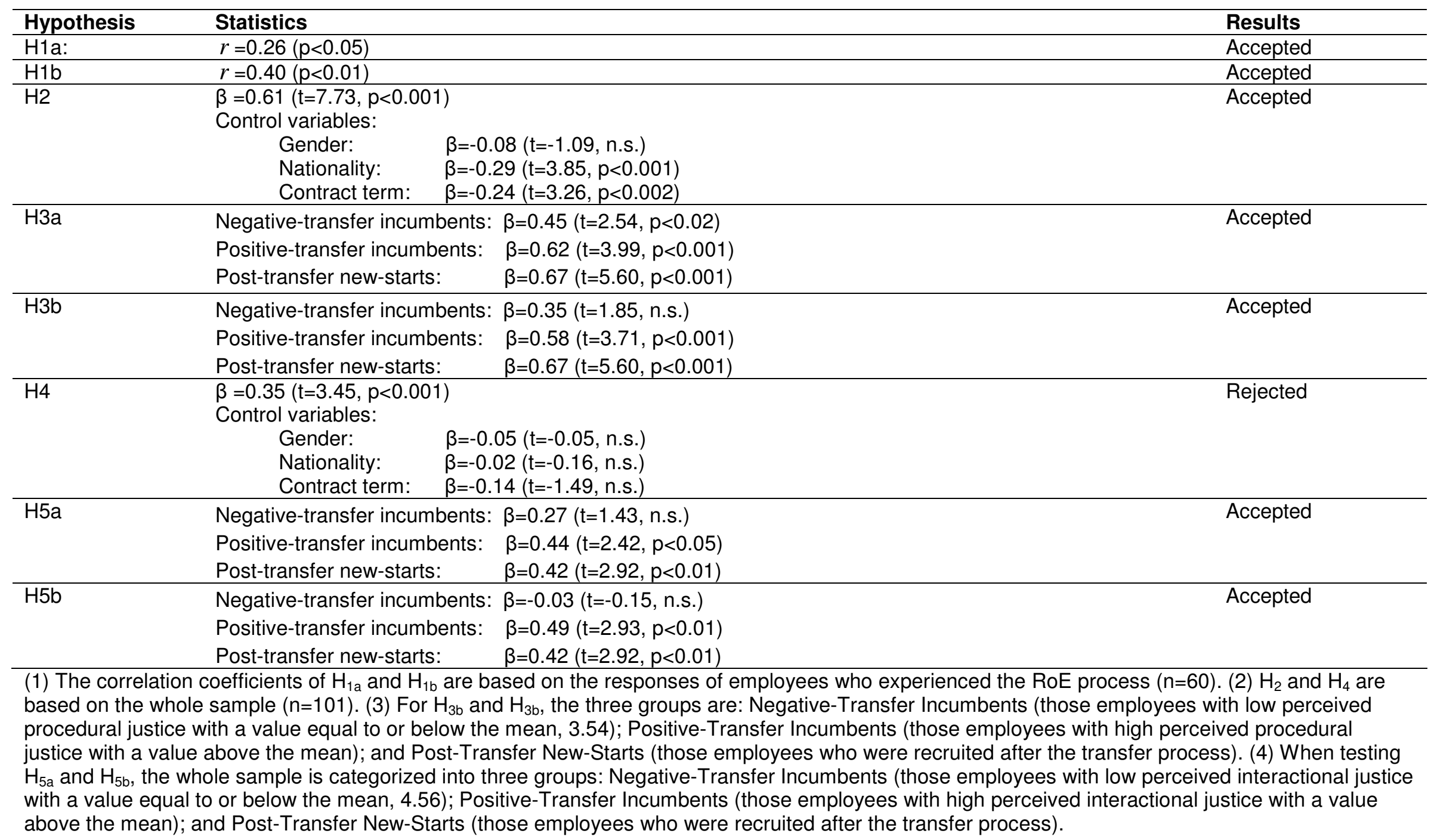

